\title{
2 \\ ONCE A REFUGEE, ALWAYS A REFUGEE? \\ The haunting of the refugee label in resettlement
}

\author{
Melanie Baak ${ }^{1}$
}

So I have a new name - refugee

Strange that a name should take away from me

My past, my personality and hope

Strange refuge this.

So many seem to share this name - refugee

Yet we share so many differences.

I find no comfort in my new name

I long to share my past, restore my pride,

To show, I too, in time, will offer more

Than I have borrowed.

For now the comfort that I seek

Resides in the old yet new name

I would choose - friend.

Ruvimbo Bungwe, aged 9 or 14 depending on source, from Zimbabwe

1 Acknowledgements: I would like to acknowledge that the thinking and work that informed this chapter was undertaken on the lands of the Nukunu and Kaurna people and pay my respects to ancestors and Elders past, present and emerging. I would also like to acknowledge the work of my colleagues, Emily Miller, Associate Professor Anna Sullivan and Associate Professor Kathleen Heugh, on the research project from which a component of data is used in this chapter. Finally, l'd like to thank all those from across the world who have shared their stories of refugee experiences with me over many years.

2 Iris Teichmann, Credit to the Nation: Refugee Contributions to the UK (London: Refugee Council, 2002). 
On International Refugee Day 2018, Danijel Malbasa, a Melbournebased industrial relations lawyer and a refugee of the Yugoslav wars, wrote of his desire growing up to distance himself from his refugee identity. He worked hard to 'scrub out my strong Slavic accent, develop an Aussie drawl, take out the letter " $j$ " from my name, even better anglicise it to "Dan", get out of the ESL class' and in doing this to 'pass' as Australian, to shun all the 'stereotypical baggage that comes with declaring oneself a refugee. ${ }^{3}$ Similarly, my own father was the child of post-World War II refugees from Poland and Russia resettled in Australia. My father began school as Henrik, not speaking a word of English, shortly thereafter he became Henry and fairly quickly forgot most of the Polish and Russian he spoke as a child. Like Danijel and my father, many former refugees have written of the desire to escape the 'refugee' label. Hannah Arendt, for example, in her seminal essay 'We Refugees' suggests that ' $[\mathrm{i}] \mathrm{n}$ the first place, we don't like to be called "refugees". We ourselves call each other "newcomers" or "immigrants". ${ }^{4}$ Ruvimbo Bungwe (cited above) at a very young age identified the desire to resist the naming 'refugee'.

Both Danijel and my father could take these actions to 'pass' as Australians and shun their refugee backgrounds because they were young, 'white' people of Eastern European refugee background resettled in Australia, and thus had some of the characteristics of 'whiteness' required to pass in Australia. ${ }^{5}$ The cultural and ethnic diversity of Australia has shifted significantly since my father was a five-year-old in the 1950s. Jupp identifies that in 1947, Australians were 99 per cent white and 96 per cent Anglo-Celtic. ${ }^{6}$ During the peak period of Yugoslav resettlement in Australia in the early 1990 s, approximately 82 per cent of Australians spoke English as their first language. ${ }^{7}$ The 2016 Australian census identified that 21 per cent of Australians speak a language other than

3 Danijel Malbasa, 'I Used to Distance Myself from my Refugee Identity. Now I Own It', Guardian, 20 June 2018, available at: www.theguardian.com/commentisfree/2018/jun/19/i-used-to-distancemyself-from-my-refugee-identity-now-i-own-it.

4 Hannah Arendt, 'We Refugees', in Altogether Elsewhere: Writers on Exile, ed. M Robinson (Boston: Faber and Faber, 1994), 110.

5 Val Colic-Peisker, “At Least You're the Right Colour": Identity and Social Inclusion of Bosnian Refugees in Australia', Journal of Ethnic and Migration Studies 31, no. 4 (2005), doi.org/10.1080/ 13691830500109720.

6 James Jupp, Immigration, 2nd ed. (Melbourne: Oxford University Press, 1998), 132.

7 James Jupp, 'From "White Australia" to "Part of Asia": Recent Shifts in Australian Immigration Policy Towards the Region', International Migration Review 29, no. 1 (1995): 211, doi.org/10.2307/ 2547002. 
English at home and 33 per cent were born outside of Australia. ${ }^{8}$ While the ethnic and linguistic diversity of Australia has shifted significantly since the ending of the official 'White Australia' policy in 1973, ${ }^{9}$ Australia is still perceived as a 'white nation'. The concept of 'race' has always been and continues to be central to political debates in Australia on issues such as immigration and national identity. These political debates in turn influence the everyday experiences of those who are 'marked' by their race. Having a 'visibly different' appearance, whether on the basis of skin colour or religious markers (such as wearing Islamic dress), results in a very different resettlement experience than those refugees who can pass in the 'invisibility' of 'whiteness' in Australia. While Danijel writes that he has recently learnt to 'own' his refugee identity after 'hiding' it for many years, this raises a number of questions. Why do some people with refugee experience resettled in countries such as Australia feel the need to distance themselves from their refugee background? What are the experiences of refugees resettled in countries such as Australia who can't 'pass' as Australian, whose visible difference can't be erased - whether by virtue of their skin colour or religion or whose audible difference can't be silenced? This chapter explores these questions. First by interrogating the framing of refugees in media, political and broader discourse. Second, by focusing on the experiences of former refugees who have been resettled in Australia.

For those who have lived in uncertain, protracted refugee situations with little hope of repatriation to their countries of birth and limited options for integration into countries of first asylum, resettlement can be seen as a dreamlike aspiration. The numbers of those resettled globally each year are a tiny number of the recognised refugees globally. In the 12 months to June 2018, approximately 102,800 of the recognised 25.4 million refugees, or 0.4 per cent, were resettled. ${ }^{10}$ While the number of resettled refugees are a very small percentage of the overall number of displaced people globally, those who are resettled live their lives at the intersection of the multiple framings of refugeeness. They bring the refugee experience into direct contact with the Western frames of understanding what it means

8 'Cultural Diversity in Australia', Australian Bureau of Statistics, 28 June 2017, available at: www. abs.gov.au/ausstats/abs@.nsf/Lookup/by\%20Subject/2071.0 2016-Main\%20Features-Cultural\%20 Diversity\%20Data\%20Summary -30 .

9 James Jupp, From White Australia to Woomera: The Story of Australian Immigration (Melbourne: Cambridge University Press, 2002), doi.org/10.1017/cbo9781139195034.

10 'Figures at a Glance', UNHCR.org, as at June 2018, available at: www.unhcr.org/en-au/figuresat-a-glance.html. 
to be a refugee. In a country such as Australia, for example, where over 220,000 people from refugee backgrounds were resettled in the period from 2000 to $2019,{ }^{11}$ these people, their experiences and the resultant research play a significant role in shaping perceptions and understanding of forced migration and refugees. In the past 20 years, resettlement has mainly been concentrated in a relatively small number of countries, primarily the United States, Canada, Australia, the Nordic countries and, increasingly, Europe. Given the geographical locations in which refugees have predominantly been resettled, interrogating the framing of refugees in these countries is crucial to understanding the ways in which former refugees are likely to be 'seen' and understood in their new home countries.

After resettlement, many former refugees continue to be referred to as 'refugees', even when resettlement entails a formal bureaucratic relabelling as permanent residents and then later as citizens. Labelling of those who have been resettled as 'refugees' continues in much academic ${ }^{12}$ and media discourse. ${ }^{13}$ This labelling continues for long after former refugees become permanent residents and citizens. For example, a recent research article refers to children born of parents with refugee experience who have lived in the UK for all or most of their lives as 'second generation refugees'. ${ }^{14}$ The question becomes: when, if ever, do people who have been refugees stop being refugees (with all of the frames of reference this entails)?

11 Janet Phillips, 'Australia's Humanitarian Program: A quick guide to the statistics since 1947', 2017, available at: www.aph.gov.au/About_Parliament/Parliamentary_Departments/Parliamentary_ Library/pubs/rp/rp1617/Quick_Guides/HumanitarianProg; Department of Home Affairs, 'Austraila's offshore Humanitarian Program: 2018-19', 2019, available at: www.homeaffairs.gov.au/ research-and-stats/files/australia-offshore-humanitarian-program-2018-19.pdf.

12 See, for example, Mark Brough et al., 'Young Refugees Talk About Well-Being: A Qualitative Analysis of Refugee Mental Health from Three States', Australian Journal of Social Issues 38, no. 2 (2003), doi.org/10.1002/j.1839-4655.2003.tb01142.x; Peter Browne, The Longest Journey: Resettling Refugees from Africa (Sydney: University of New South Wales Press, 2006); Clemence Due, "Who are Strangers?": "Absorbing" Sudanese Refugees into a White Australia', ACRAWSA E-Journal 4, no. 1 (2008), available at: acrawsa.org.au/wp-content/uploads/2017/12/CRAWS-Vol-4-No-1-2008-1.pdf. 13 See, for example, Piers Ackerman, 'Refugee Fury at Africa Ban; Sudanese: Minister Insulted Us', Sunday Mail, 14 October 2007, available at: www.news.com.au/adelaidenow/ story/0,22606,22581759-5006301,00.html (site discontinued); Elissa Hunt, 'Killers who Bashed Sudanese Refugee Liep Gony to Death can be Identified after Herald Sun Campaign', Herald Sun, 18 February 2010, available at: www.heraldsun.com.au/news/killers-who-bashed-saudaneserefugee-liep-giny-to-death-can-be-identified-after-herald-sun-campaign/news-story/35af7b625d 754b6d4643a40d072ae026; Ben Schneiders, 'Refugees Fear for Future, Say Leaders', Age (Melbourne), 23 October 2007, available at: www.theage.com.au/news/national/refugees-fear-for-future-say-leade rs/2007/10/22/1192940985058.html.

14 Alice Bloch and Shirin Hirsch, "Second Generation" Refugees and Multilingualism: Identity, Race and Language Transmission', Ethnic and Racial Studies 40, no. 14 (2017), doi.org/10.1080/014 19870.2016.1252461. 
To interrogate this question, this chapter will highlight the development of frames of understanding the refugee, then dialogue these with everyday experiences of people from refugee backgrounds resettled in countries such as Australia. The chapter presents a small component of a research project conducted with students with refugee experience in secondary schools as well as drawing on literature, writing by people from refugee backgrounds such as Danijel Malbasa ${ }^{15}$ and personal experience with people from refugee backgrounds over the past 15 years. This chapter will provide examples of the ways in which 'race' and racialisation of the refugee underpin how refugees are seen and understood as well as the ways in which the refugee label continues to haunt former refugees who are resettled in third countries such as the United States, the United Kingdom, Australia and Canada.

In this chapter I use the term 'haunt' to understand the ways in 'which abusive systems of power make themselves known and their impacts felt in everyday life. ${ }^{16}$ To be haunted, Gordon argues:

is to be tied to historical and social effects ... these ghostly aspects of social life are not aberrations, but are central to modernity itself ... The ghostly phantom objects and subjects of modernity have a determining agency on the ones they are haunting. ${ }^{17}$

Through tracing the framing of the refugee and the everyday experiences of this framing, I argue that there are 'abusive systems of power' in place that haunt refugees and former refugees and have a 'determining agency' that positions them as always already in deficit and as objects in need of assistance. Through tracing the development of the refugee label and explicating how the label is enacted and experienced in everyday lives, I argue that it is not the refugee label that needs to be escaped/exorcised but the frames of reference through which the refugee experience is understood.

15 Malbasa, 'I Used to Distance Myself from my Refugee Identity. Now I Own It'.

16 Avery F Gordon, Ghostly Matters: Hauntings and the Sociological Imagination (Minneapolis:

University of Minnesota Press, 2008), xvi.

17 Ibid., 190-201. 


\section{Framing the refugee}

The word 'refugee' can be traced to its origins in the French word réfugié that was used to identify the Huguenots, tens of thousands of Reformed Protestant French migrants who escaped the French Catholic monarch to live in other non-Catholic European countries at the time. ${ }^{18}$ While the 'legal and moral status' ${ }^{19}$ of refugees was crystallised with the development of the 1951 Convention Relating to the Status of Refugees, ${ }^{20}$ the ways in which refugees are understood by the broader population, particularly in countries in which they are given refuge, has shifted and changed, and been influenced by wider cultural and political rhetoric. Canadian historian Michael Ignatieff argues that currently 'new metaphors have entered the democratic body politic, categorizing the refugee not as an individual with rights and a moral claim, but as the invasive other' ${ }^{21}$ Visual, political and discursive fields operate to construct frames that position refugees not only as Other, but as a threatening, undesired Other. Butler argues that certain normative processes operate to 'produce certain subjects as "recognizable" persons and to make others decidedly more difficult to recognize'.22 Through processes of framing particular populations, such as refugees, these normative processes make refugees inherently more difficult to recognise as subjects and thereby human. In order to understand the ways in which these normative processes have operated to produce refugees as infinitely less 'recognizable' persons, it is important to trace the ways in which refugees have been labelled and understood.

A number of important research articles have interrogated the labelling of refugees. Roger Zetter's original paper 'Refugees and Refugee Studies - A Label and an Agenda ${ }^{23}$ articulated a framing of the refugee that continues in a similar vein 30 years later:

in the present century it is the word 'refugee' which has increasingly been deployed to describe the millions of uprooted people who have been forced into exile or displaced within their

18 Leo Hornak, 'The Word "Refugee" has a Surprising Origin', Public Radio International, 20 February 2017, available at: www.pri.org/stories/2017-02-20/word-refugee-has-surprising-origin.

19 Michael Ignatieff, 'The Refugee as Invasive Other', Social Research: An International Quarterly 84, no. 1 (2017): 223.

20 Convention Relating to the Status of Refugees, opened for signature 28 July 1951, 189 UNTS 150 (entered into force 22 April 1954).

21 Ignatieff, 'The Refugee as Invasive Other', 223.

22 Judith Butler, Frames of War: When is Life Grievable?, 2nd ed. (London: Verso, 2010), 6.

23 Roger Zetter, 'Refugees and Refugee Studies - A Label and an Agenda', Journal of Refugee Studies 1, no. 1 (1988): 1-6, doi.org/10.1093/jrs/1.1.1. 
own countries because of intolerance, war or other human factors. 'Refugee' constitutes one of the most powerful labels currently in the repertoire of humanitarian concern, national and international public policy and social differentiation. The label 'refugee' both stereotypes and institutionalises a status. It is benevolent and apolitical, yet it also establishes, through legal and policy making practices, highly politicised interpretations (Wood 1985). It may designate crisis needs and the associated conditions of poverty and deprivation. Conversely it encompasses longer term issues of resettlement and assimilation. ${ }^{24}$

Zetter's subsequent works, particularly 'Labelling Refugees: Forming and Transforming a Bureaucratic Identity' ${ }^{25}$ and 'More Labels, Fewer Refugees: Remaking the Refugee Label in an Era of Globalization', ${ }^{26}$ continue to explore the ways in which bureaucratic action forms and transforms the framing and identification, as well as the identities, of refugees. He argues, along with others such as Malkki, ${ }^{27}$ that humanitarian agencies and interventions in refugee situations have resulted in a 'focus on refugees as their object of knowledge, assistance, and management'. ${ }^{28}$ Chimni develops these arguments, suggesting that through the objectification of refugees, understandings of refugees have been constructed through a 'western strategy to employ political humanitarianism'. ${ }^{29}$ Through this focus on refugees as an object of knowledge, refugees have become 'an object of concern and knowledge for the "international community," and for a particular variety of humanism'. ${ }^{30}$ The objectification of refugees has seen refugees represented as ahistorical, apolitical, victims,

24 Zetter, 'Refugees and Refugee Studies - A Label and an Agenda', 1.

25 Roger Zetter, 'Labelling Refugees: Forming and Transforming a Bureaucratic Identity', Journal of Refugee Studies 4, no. 1 (1991), doi.org/10.1093/jrs/4.1.39.

26 Roger Zetter, 'More Labels, Fewer Refugees: Remaking the Refugee Label in an Era of Globalization', Journal of Refugee Studies 20, no. 2 (2007), doi.org/10.1093/jrs/fem011.

27 Liisa H Malkki, 'National Geographic: The Rooting of Peoples and the Territorialization of National Identity Among Scholars and Refugees', in Culture, Power, Place: Explorations in Critical Anthropology, ed. Akhil Gupta and James Ferguson (Durham, NC: Duke University Press, 1997), doi. org/10.1215/9780822382089-002; Liisa H Malkki, Purity and Exile: Violence, Memory, and National Cosmology among Hutu Refugees in Tanzania (Chicago: The University of Chicago Press, 1995), doi. org/10.7208/chicago/9780226190969.001.0001; Liisa H Malkki, 'Refugees and Exile: From "Refugee Studies" to the National Order of Things', Annual Review of Anthropology 24 (1995), doi.org/10.1146/ annurev.an.24.100195.002431; Liisa H Malkki, 'Speechless Emissaries: Refugees, Humanitarianism, and Dehistoricization', Cultural Anthropology 11, no. 3 (1996), doi.org/10.1525/can.1996.11.3.02a00050.

28 Malkki, 'Speechless Emissaries', 377.

29 B S Chimni, 'The Birth of a "Discipline”: From Refugee to Forced Migration Studies', Journal of Refugee Studies 22, no. 1 (2009): 13, doi.org/10.1093/jrs/fen051.

30 Malkki, 'Speechless Emissaries', 378. 
'universal humanitarian subjects', ${ }^{31}$ in need of 'fixing by state actors and aid providers', ${ }^{32}$ as 'undesirable elements disruptive to the national order of things', ${ }^{33}$ who are recognised through 'racializing schemes that serve to blacken and stigmatize'. ${ }^{34}$

Photojournalism, film, the media and the state have all shaped the positioning of 'refugees' in particular ways. ${ }^{35}$ The images that circulate in the media 'play a central role in framing how refugees are publicly perceived and politically debated'. ${ }^{36}$ Media images and political discourses have framed understandings of the refugee such that, on hearing the word refugee, many people imagine images of refugee camps, hunger, war, conflict and trauma. Others think of current political discourses globally around 'asylum seekers', 'queue jumpers', 'terrorists' and fear. International and national discourses around the 'refugee crisis' see current events framed in ways that sensationalise the 'problem' of the refugee. ${ }^{37}$ For refugees, certain representational conventions 'have coagulated into a standard discursive mode that one finds routinely in journalistic writing and other news media. ${ }^{38}$ Through representations of refugees as 'needy' victims who have experienced trauma, ${ }^{39}$ they are frequently portrayed as

31 Ibid.

32 Sara L McKinnon, 'Unsettling Resettlement: Problematizing "Lost Boys of Sudan" Resettlement and Identity', Western Journal of Communication 72, no. 4 (2008): 397, doi.org/10.1080/105703108 02446056.

33 Bishupal Limbu, 'Illegible Humanity: The Refugee, Human Rights and the Question of Representation', Journal of Refugee Studies 22, no. 3 (2009): 268, doi.org/10.1093/jrs/fep021.

34 Aihwa Ong, Buddha is Hiding: Refugees, Citizenship, the New America (Berkeley: University of California Press, 2003), 13.

35 Melanie Baak, 'Murder, Community Talk and Belonging: An Exploration of Sudanese Community Responses to Murder in Australia', African Identities 9, no. 4 (2011), doi.org/10.1080/14725843. 2011.614415; Prem Kumar Rajaram, 'Humanitarianism and Representations of the Refugee', Journal of Refugee Studies 15, no. 3 (2002).

36 Roland Bleiker et al., 'The Visual Dehumanisation of Refugees', Australian Journal of Political Science 48, no. 4 (2013): 402.

37 Marlou Schrover and Willem Schinkel, 'Introduction: The Language of Inclusion and Exclusion in the Context of Immigration and Integration', Ethnic and Racial Studies 36, no. 7 (2013), doi.org/ $10.1080 / 01419870.2013 .783711$.

38 Limbu, 'Illegible Humanity', 268.

39 Laura Bates et al., 'Sudanese Refugee Youth in Foster Care: The "Lost Boys" in America', Child Welfare Journal 84, no. 5 (2005); Brough et al., 'Young Refugees Talk About Well-Being'; Kaaren FraterMathieson, 'Refugee Trauma, Loss and Grief: Implications for Intervention', in Educational Interventions for Refugee Children: Theoretical Perspectives and Implementing Best Practice, ed. Richard Hamilton and Dennis Moore (London: RoutledgeFalmer, 2004), doi.org/10.4324/9780203687550; Jay M Marlowe, 'Beyond the Discourse of Trauma: Shifting the Focus on Sudanese Refugees', Journal of Refugee Studies 23, no. 2 (2010), doi.org/10.1093/jrs/feq013; Robert Schweitzer et al., 'Trauma, Post-Migration Living Difficulties, and Social Support as Predictors of Psychological Adjustment in Resettled Sudanese Refugees', Australian \& New Zealand Journal of Psychiatry 40, no. 2 (2006), doi.org/10.1080/j.14401614.2006.01766.x. 
undesirable 'parasites' of the state ${ }^{40}$ who are unwilling or unable to find employment, ${ }^{41}$ unlikely or unable to succeed at school without significant state-funded support ${ }^{42}$ and unwilling or unable to integrate within the host community. ${ }^{43}$ The re-inscription of representations of 'refugees', then, works to preclude refugees from inclusion into the communities to which they are resettled.

These standard discursive modes have resulted in what Adichie refers to as the 'single story'. ${ }^{44}$ The 'danger of the single story' is that it serves to rob people of their dignity and make 'our recognition of our equal humanity difficult'. ${ }^{45}$ The discourses and images, the 'single story' of refugees, not only haunt the ways in which the broader population understands refugees in the countries in which they first seek asylum, but these framings also follow refugees to the countries in which they are resettled. Through representations of 'the refugee', anonymising and dehumanising narratives are allowed, and even encouraged, to permeate. These singular, deficit views overlook the 'complex and oftentimes contradictory humanity and subjectivity'46 that underscores how refugees negotiate their lives. It limits

40 Mireille Rosello, Postcolonial Hospitality: The Immigrant as Guest (California: Stanford University Press, 2001); Alison Saxton, "I Certainly Don't Want People Like That Here": The Discursive Construction of "Asylum Seekers", Media International Australia 109, no. 1 (2003), doi.org/10.1177/ 1329878x0310900111.

41 Val Colic-Peisker, 'The "Visibly Different" Refugees in the Australian Labour Market: Settlement Policies and Employment Realities', in Refugees, Recent Migrants and Employment: Challenging Barriers and Exploring Pathways, ed. S McKay (New York: Routledge, 2009), doi.org/10.4324/ 9780203890745 .

42 Lutine de Wal Pastoor, 'Rethinking Refugee Education: Principles, Policies and Practice from a European Perspective', Annual Review of Comparative and International Education 2016, vol. 30 (2016), doi.org/10.1108/s1479-367920160000030009; Rachel Hek, 'The Role of Education in the Settlement of Young Refugees in the UK: The Experiences of Young Refugees', Practice 17, no. 3 (2005), doi.org/10.1080/09503150500285115; Jody Lynn McBrien, 'Educational Needs and Barriers for Refugee Students in the United States: A Review of the Literature', Review of Educational Research 75, no. 3 (2005), doi.org/10.3102/00346543075003329; Emily Miller, Tahereh Ziaian and Adrian Esterman, 'Australian School Practices and the Education Experiences of Students with a Refugee Background: A Review of the Literature', International Journal of Inclusive Education (2017), doi.org/10.1080/13603116.2017.1365955.

43 Surjeet Dhanji, 'Welcome of Unwelcome? Integration Issues and the Resettlement of Former Refugees from the Horn of Africa and Sudan in Metropolitan Melbourne', The Australasian Review of African Studies 30, no. 2 (2009); Kerstin Lueck, Clemence Due and Martha Augoustinos, 'Neoliberalism and Nationalism: Representations of Asylum Seekers in the Australian Mainstream News Media', Discourse \& Society 26, no. 5 (2015), doi.org/10.1177/0957926515581159; Alison Strang and Alastair Ager, 'Refugee Integration: Emerging Trends and Remaining Agendas', Journal of Refugee Studies 23, no. 4 (2010), doi.org/10.1093/jrs/feq046.

44 Chimamanda Ngozi Adichie, 'The Danger of a Single Story' (talk, TEDGlobal 2009), available at: www.ted.com/talks/chimamanda_adichie_the_danger_of_a_single_story/transcript.

45 Adichie, 'The Danger of a Single Story'.

46 Gordon, Ghostly Matters, 4. 
them to being understood and seen as always and only refugees, with all the ghosts that this entails, and homogenises the multiple lives to a single experience. As Turton has argued, for refugees, the discourse of forced migration:

helps to make it possible for states, governments and the publics of host countries, especially rich Northern ones, to respond to forced migrants not as individual human beings, people like us, embedded in contingent social and historical circumstances, but as anonymous and dehumanised masses. As people who are members neither of our civil nor our moral community. ${ }^{47}$

With this dehumanisation of the refugee experience, it becomes clear that the lives of refugees have become dissociated from the human in a way that makes their lives less recognisable. To interrogate the ways in which we might shift these frames, Butler argues that it is essential to call these frames into question - 'to show that the frame never quite contained the scene it was meant to limn, that something was already outside, which made the very sense of the inside possible, recognizable'. ${ }^{48}$ To do this requires not only the production of new frames, but also a reworking of the existing frames through which it 'becomes possible to apprehend something about what or who is living but has not been generally "recognized" as a life. ${ }^{49}$ While there is effort in the alternative media (i.e. media sources that do not seek to represent government and corporate interests as the mainstream media does) ${ }^{50}$ and in various research to produce new frames of understanding the refugee experience, ${ }^{51}$ there is still significant work required to rework the existing frames. In the sections that follow, I provide examples from a research project that identify how frames of understanding the refugee are enacted in everyday life. However, the research examples also emphasise the ways people with refugee experience struggle to resist these framings.

47 David Turton, 'Conceptualising Forced Migration' (RSC Working Paper No. 12, 2003): 10, available at: www.rsc.ox.ac.uk/files/files-1/wp12-conceptualising-forced-migration-2003.pdf.

48 Butler, Frames of War: When is Life Grievable?, 9.

49 Ibid., 12.

50 Edward S Herman and Noam Chomsky, Manufacturing Consent: The Political Economy of the Mass Media (Random House, 2010), doi.org/10.2139/ssrn.1977265.

51 See, for example, Melanie Baak, Negotiating Belongings: Stories of Forced Migration of Dinka Women from South Sudan (Rotterdam: Sense Publishers, 2016), doi.org/10.1007/978-94-6300-588-3; Behrouz Boochani, No Friend but the Mountains: Writing from Manus Prison, trans. Omid Tofighian (Sydney: Picador, 2018); Laurent Van Lancker, Kalès (Polymorfilms, 2017); Olivia Woldemikael, 'A Crisis of Definition Rehumanising the Refugee', Real Media, 2017, available at: realmedia.press/acrisis-of-definition-rehumanising-the-refugee/ (site discontinued). 


\section{Research context}

This chapter is informed by over 15 years of personal and professional experience living and working with people of various refugee backgrounds in a number of different countries and contexts. As a white Anglo Australian woman who is married to a South Sudanese Australian of refugee background, my understandings are informed by his experiences as well as those of his family, friends and community. I have also spent time living with South Sudanese refugees in Kenya and Uganda. Over the past 11 years I have undertaken a number of different research projects exploring different aspects of the resettlement experience for refugees in Australia and in Scotland, particularly focused on schooling, but also on broader contexts including employment, health and social inclusion. While these experiences inform this chapter, the data presented in what follows largely draw on a project I recently undertook with colleagues entitled 'Improving Educational Outcomes for Students from Refugee Backgrounds in the South Australian Certificate of Education: A Case Study of Two Catholic Secondary Schools'. ${ }^{52}$ The aim of the project was to explore how schools support students with refugee experience undertaking the senior secondary certificate of education, and was focused on evaluating an intervention that was introduced in the two participating schools to support students with refugee experience. Case studies were undertaken in two secondary schools. The data included online surveys with school staff $(n=34)$ and students $(n=29)$, one focus group with teachers in each school $(\mathrm{n}=17)$, one focus group with students in each school $(\mathrm{n}=16)$, and individual interviews with five teachers and five students in each school $(\mathrm{n}=20)$. This chapter specifically focuses on themes that arose during the research at one of the schools, which was a girlsonly school where approximately 60 per cent of students spoke English as an Additional Language and almost 40 per cent of students came from a refugee background. School staff were requested to identify students from refugee backgrounds for participation; this was usually done by the English as an Additional Language specialist teacher or by an educational support officer who worked closely with the culturally and linguistically diverse students at the school. The school staff reported that students were identified for participation based both on 'visa type' identified in school

52 Melanie Baak et al., 'Improving Educational Outcomes for Students from Refugee Backgrounds in the South Australian Certificate of Education Project: A Case Study of Two Catholic Schools' (University of South Australia, 2018), available at: apo.org.au/node/136916. 
enrolment records as well as on knowing the students. The study was not specifically about exploring the refugee label or experience. However, what became obvious very early in the project, particularly at the girlsonly secondary school, was a reluctance from the students to be identified as refugee background students. Some of the reasons for this possible reluctance to be identified as 'refugee students' will be explored in the sections below.

\section{The haunting of the refugee label: Who is a refugee and for how long?}

The word refugee stalks you through life prefixed to any other subsequent identity you develop in post-refugee life.

A 'refugee' felt like a prior identity, a political status once ascribed to me that suggested vulnerability, inferiority, alienness, pity everything I wanted to remove from my idea of myself. ${ }^{53}$

The refugee label, with all the frames of reference it entails, continues to haunt those with refugee experience through resettlement. This label has a 'determining agency' on those whom it haunts. ${ }^{54}$ As Malbasa argues, 'the word refugee stalks' suggesting 'vulnerability, inferiority, alienness, pity. ${ }^{55}$ This perhaps goes a long way in explaining why the students in our project were reluctant to be identified as refugee background students. Feedback from the teachers facilitating the recruitment of student participants suggested that the girls did not want to be identified as refugee students. Jacinta, one of the specialist support teachers who worked very closely with students from diverse backgrounds, identified that:

some of the other girls are like 'I'm not a refugee student what are you talking about' you know 'My parents came here ... because they had the skills'. So no acknowledgement whatsoever, a couple of girls in particular ... that's why - I guess I can assume that for those girls they didn't want to be part of it because they didn't want to be labelled ... And also the fact that they perhaps care about what other people think, their friends - they do care about what people are going to think about them. (Jacinta, school educational support officer)

53 Malbasa, 'I Used to Distance Myself from my Refugee Identity. Now I Own It'.

54 Gordon, Ghostly Matters, 190.

55 Malbasa, 'I Used to Distance Myself from my Refugee Identity. Now I Own It'. 
The students from refugee backgrounds who undertook the survey, focus group or interviews self-identified as being from a range of national, linguistic, cultural and religious backgrounds including Afghanistan, Burma, South Sudan, Democratic Republic of Congo and 'Muslim'. With the diversity of the school, some students from refugee backgrounds endeavoured to de-identify themselves from the label refugee. Jacinta argued that the young women 'care about what people are going to think about them' and therefore 'didn't want to be labelled'. Instead the girls preferred to identify that their parents came here 'because they had the skills' thereby identifying as skilled migrants, a category of migrant that does not have the negative framing associated with being a refugee. The quote from Jacinta suggests that some of the girls from refugee backgrounds sought to 'hide' their refugee backgrounds in the diversity of the school without having to identify with the 'refugee' label. In a similar way, Ryu and Tuvilla describe Chin youth from Burma, resettled in the United States, as recalibrating 'their refugee identity as a voluntary immigrant' and challenging the 'dominant narrative of refugees'. ${ }^{56}$ Danijel Malbasa also identifies with this experience, describing:
Better to call myself an immigrant, I decided ... To regard myself as belonging to a category of migratory humanity that is for the most part uncontroversial, less needy, less 'frightening' than a refugee..$^{57}$

A majority of the students who participated in the focus groups and interviews conducted as part of this project were comfortable with identifying as being from a refugee background. It is assumed that most of those who were uncomfortable with this labelling chose not to participate. However, one female participant, Gloria, a young woman from an African country who was in Year 11 at the time of the research, rejected identification as a refugee, highlighting her father's employment. Gloria was identified by the school for participation in the project based on her refugee background. However, when asked about this, Gloria did not identify as being from a refugee background.

Interviewer: And so you came when you were two, did your family come as refugees?

\footnotetext{
56 Minjung Ryu and Mavreen Rose S Tuvilla, 'Resettled Refugee Youths' Stories of Migration, Schooling, and Future: Challenging Dominant Narratives about Refugees', The Urban Review (2018), doi.org/10.1007/s11256-018-0455-z.

57 Malbasa, 'I Used to Distance Myself from my Refugee Identity. Now I Own It'.
} 
Gloria: Not really. Dad he kind of grew up in the city so he's like - and so he got offered a job here in Sydney, so he came first and then we came - he brought us after.

As well as demonstrating Gloria's self-identification as an immigrant, this excerpt presents two additional questions for labelling refugees. First, if Gloria did not identify as being from a refugee background, on what basis was she recruited by the school staff to participate in the research? Second, even if Gloria was from a refugee background, if she came to Australia when she was two and she was in Year 11 at the time of the interview (making her about 17 years old), should this refugee label still be following her 15 years after arrival in Australia? I hypothesise that the racialisation of refugees in Australia plays a significant part in the haunting of the refugee label particularly for those, like Gloria, who are of 'black' African appearance. In the sections that follow, I first argue for the role of racialisation in the identification of people as refugees and finally I explore the question of how long a refugee remains a refugee.

\section{'This black refugee ...': Racialisation of the refugee in countries of hegemonic whiteness}

Gloria, like other arrivals to Australia of African descent, has become part of a complex, racialised country. Since colonisation, Australia has been a nation of settlers. ${ }^{58}$ But since this time, the hegemonically 'white' Australian national identity continues to be unsettled by the presence of non-'white' Indigenous Australians and the arrival of non-'white' migrants and refugees. The White Australia policy, which was only officially disbanded in the early 1970s, aimed to promote and strengthen the 'white' European national identity. The numbers of 'black' Africans in Australia has historically been quite low. In 1971, census data estimated that 61,935 African-born people lived in Australia and over 20 per cent of these were born in South Africa, with a significant number being 'children of colonial functionaries and Anglo Saxons from Southern Africa'. ${ }^{59}$ By 2006, the African-born population in Australia had increased significantly, with

58 Pal Ahluwalia, 'When Does a Settler Become a Native? Citizenship and Identity in a Settler Society', Pretexts: Literary and Cultural Studies 10, no. 1 (2001), doi.org/10.1080/713692599.

59 Graeme Hugo, 'Migration Between Africa and Australia: A Demographic Perspective' (Sydney: Australian Human Rights Commission, 2009): 15. 
approximately 248,699, of whom approximately 42 per cent were South African. ${ }^{60}$ From the late 1990s, Australia has accepted significant numbers of African-born refugees through the humanitarian entrant program. In the period from 2004 to 2016, the largest sources of resettled refugees to Australia included Burma, Iraq, Bhutan, Somalia, Syria and South Sudan. For a country still rooted in denial of the original owners of the land, a nation founded on ideals of white superiority and with a history of white migration, ${ }^{61}$ the significant recent arrivals of refugees, particularly from Horn of Africa countries and Middle Eastern countries, have continued to unsettle these 'white' ideals. Phenotypical characteristics as well as other markers of visible difference, such as Islamic female dress or veils, mark refugees as culturally and/or religiously different from the hegemonically white identity that is still presumed to be 'Australian'.

Gloria was identified by her school as being from a refugee background despite not self-identifying as a refugee and having lived in Australia for 15 of her 17 years. She was of 'black' African appearance. This demonstrates the tendency to conflate blackness with refugeeness in Australia. While Phillips, in her analysis of the labelling of South Sudanese Australians as a refugee group, argues that Sudanese Australians are 'generally understood to be refugees', ${ }^{62}$ I would take this further to propose that 'black' Africans in Australia are frequently assumed to be refugees. The conflation of blackness with refugeeness was also described by participants in my $\mathrm{PhD}$ research. My PhD project explored the experiences of belonging for five Dinka women from South Sudan who were resettled in Australia, through in-depth qualitative ethnographic and life history approaches. ${ }^{63}$ Achol, for example, described an experience at her daughter's school:

But when I was moving here this house, I take children to Greenhills Primary School. Other girls to fighting with the Ayak [my daughter] in the school. Other woman coming, she tell me 'This one refugees, refugees ... [switches to Dinka] this black refugee. How could she beat my child?' ... Then I was called to the meeting, there was a translator, and I had already been informed by Ayak that there was a woman who was angry with me in the school. Then the headmaster asked me through the interpreter,

60 Hugo, 'Migration Between Africa and Australia', 16.

61 Jupp, 'From "White Australia" to "Part of Asia"'.

62 Melissa Phillips, 'Convenient Labels, Inaccurate Representations: Turning Southern Sudanese Refugees into "African-Australians"', Australasian Review of African Studies 32, no. 2 (2011): 57-79 (emphasis added).

63 Reported extensively in Baak, Negotiating Belongings. 
and I replied that 'If you people say you don't want my child in the school because she is a black refugee, then I will take her to another school.' ${ }^{64}$

Achol described another mother at her daughter's school identifying her as a 'black refugee' thereby conflating blackness and refugeeness. Ramsay argues that 'experiences of racialisation toward women who are resettled in Australia from Central African countries ... reflect a colonial imaginary and a legacy of postcolonising dominance in Australia' with 'assumptions of difference, dirtiness, and savagery' attached to the women. ${ }^{65}$ Similarly, Kumsa, in a study of young Oromo refugees in Toronto argues that the 'refugee' label is used as a label of exclusion to further distance people from belonging to the nation. ${ }^{66} \mathrm{With}$ the negative framing of the refugee that positions those with refugee background as always in deficit as described above, it is hardly any wonder that those with refugee backgrounds endeavour to find other labels and identities without these framings with which they can be identified.

For African-born Australians, blackness and refugeeness are conflated as a double negative relegating them to a form of perpetual foreignness. In a similar way, the association of Muslim immigrants and refugees with threats of terrorism results in them being 'considered suspicious and consequently less desirable'. ${ }^{67}$ This results in visible markers of Islamic faith also being frequently associated with refugeeness. Colic-Peisker further argues that European refugees and immigrants 'do not face their own racial "visibility" as a barrier to inclusion' in Australia. ${ }^{68}$ The visible difference of most refugee groups results in the humanitarian resettlement program being 'the most contentious immigration category'. ${ }^{69}$ These experiences of visibly different refugees, whose blackness or religious Otherness position them as perpetual refugees, sit in stark contrast to the 'white' Bosnian refugees Colic-Peisker interviewed in her research. The Bosnian refugees, like Malbasa described above, were able to distance themselves from

64 Baak, Negotiating Belongings, 58-59.

65 Georgina Ramsay, 'Central African Refugee Women Resettled in Australia: Colonial Legacies and the Civilising Process', Journal of Intercultural Studies 38, no. 2 (2017): 170, doi.org/10.1080/07 256868.2017.1289904.

66 Martha Kuwee Kumsa, “'No! I'm not a Refugee!” The Poetics of Be-Longing Among Young Oromos in Toronto', Journal of Refugee Studies 19, no. 2 (2006), doi.org/10.1093/jrs/fel001.

67 Colic-Peisker, “'At Least You’re the Right Colour”, 619.

68 Ibid., 619.

69 Ibid., 619. 
their refugee identity, seeing themselves as 'whites in a white country ${ }^{30}$ and recounted being told by other Australians that 'at least you're the right colour'. ${ }^{71}$ The racialisation of the refugee in countries of hegemonic whiteness, such as Australia, results in them perpetually being seen as refugees regardless of how long they have lived in Australia.

\section{'I'm still a refugee ...'}

Gloria, in the excerpt quoted above, came to Australia when she was two. Yet, 15 years later, her school continued to identify her as being from a refugee background. Even if she did arrive on a refugee-related visa, 15 years of a 17 -year old's life is a very long time to continue being haunted by the refugee label. It is likely that even if Gloria did arrive in Australia on a refugee-related visa, the most likely visa program she would have come through would have been a family reunification visa through the sponsored Special Humanitarian Visa program, sponsored by her father who was already living in Australia. Resettlement through this pathway facilitates people legally becoming permanent residents in Australia as soon as they arrive. Thus, in the legal sense of the label refugee, Gloria has not been a refugee since her arrival in Australia. However, the informal label of refugee and its concomitant frames of reference have continued to haunt Gloria for 15 years, despite her legal status as permanent resident (and likely citizen). On this basis Ludwig argues that the 'legal refugee status and the informal label refugee are not, and should not be used as, synonymous terms ${ }^{72}$

The problem with the continuing haunting of the refugee label for people with refugee experience resettled in Australia was also described to me in my $\mathrm{PhD}$ research, outlined above. Abuk, a woman aged in her 50s, described in Dinka:

But we've been here for years and we are not refugees anymore.

Now I've been here for about five years and I'm not a citizen,

I'm still a refugee. ${ }^{73}$

\footnotetext{
70 Ibid., 621.

71 Ibid., 620

72 Bernadette Ludwig, "Wiping the Refugee Dust From my Feet": Advantages and Burdens of Refugee Status and the Refugee Label', International Migration 54, no. 1 (2016): 6, doi.org/10.1111/ imig. 12111.

73 Baak, Negotiating Belongings, 47.
} 
Despite arriving in Australia through Australia's humanitarian entrant program, and thereby being a permanent resident on arrival in Australia, Abuk's experience was that, even after five years living in Australia, she was still recognised and identified as a refugee. This experience resonates with other people from various refugee backgrounds in contexts of resettlement. Jumsa writes of the experiences of Oromo resettled in Canada, who, despite being citizens for over 10 years, are still seen by others, and therefore themselves, as refugees. ${ }^{74}$ Neumann and Gifford argue that 'Australian scholarship largely remains steeped in labelling resettled refugees as refugees well beyond their initial arrival in Australia. ${ }^{75}$ This is an issue not only in scholarship and research, but also in the media as well as political and everyday discourse. While legally the ending of the refugee label is clearly demarcated, there is no finite point at which people stop being seen by others, or in some instances by themselves, as refugees.

\section{Conclusion: Rehumanising the refugee}

While labelling resettled former refugees is inherently problematic, as highlighted above, without using labels such as 'refugee' or 'former refugee' or 'refugee background' it is impossible to acknowledge and recognise the previous experiences that people have had prior to resettlement in Australia. The word refugee in and of itself is not the problem: rather, it is the framing and what it represents, the social constructions of what that label means, that results in a negative framing of the former refugee. Reframing the socially constructed understanding of the term 'refugee', while notably difficult, would enable the use of the label 'refugee' without using it to Other through marginalisation and deficit understandings. As Ryu and Tuvilla suggest, in their article exploring the educational experiences of Chin former refugees resettled in the United States, there is a 'dilemma as to how to identify and accommodate their needs while not subscribing to sweeping narratives about the helpless refugees in need of support'. ${ }^{76}$

74 Kumsa, “'No! I'm not a Refugee!”.

75 Klaus Neumann and Sandra M Gifford, 'Producing Knowledge about Refugee Settlement in Australia', in Critical Reflections on Migration, 'Race' and Multiculturalism, ed. Martina Boese and Vince Marotta (Routledge, 2017), 116, doi.org/10.4324/9781315645124-7.

76 Ryu and Tuvilla, 'Resettled Refugee Youths' Stories of Migration, Schooling, and Future', 5. 
The politics of representation have seen refugees constructed as Others: as victims, lacking agency, in need of humanitarian intervention. This Othering serves to remove the human subjectivity of refugees, ${ }^{77}$ dehumanising them through a process that objectifies. As Bakewell has argued, '[b]y staring too hard at "refugees" or "forced migrants", we fail to see their "normality". ${ }^{78}$ The question then becomes, "how to reverse this dehumanization and to return the humanity to those from whom categorization has removed all individual attributes. ${ }^{79}$

To rehumanise requires really listening to and hearing the voices of those who are often not heard. It is important to recognise that really 'hearing' their stories is:

embodied in the process of mutually recognizing our claims on each other as reflexive human agents, each with an account to give, and account of our lives that needs to be registered and heard. ${ }^{80}$

It is necessary to hear narratives of former refugees and those who are resettled as more complex than those of trauma, disempowerment and victimisation inherent in research, media and public discourse. Rather we need to hear the stories of agency, subjectivity, individuality, resiliency, resentment, fear, hate, love, passion, vulnerability, strength, courage and challenge. This also requires hearing the multiple stories that these voices have to tell. As Adichie has argued:

Stories matter. Many stories matter. Stories have been used to dispossess and to malign, but stories can also be used to empower and to humanize. Stories can break the dignity of a people, but stories can also repair that broken dignity. ${ }^{81}$

The stories and lives of those from refugee backgrounds can illustrate a complexity that is so quickly lost in research that struggles to be objective and representative. An acknowledgement of this complexity is vital if former refugees are to be understood in their full humanness. As Halpern and Weinstein have observed, '[a] critical step in rehumanization is to view

77 Zygmunt Bauman, Wasted Lives: Modernity and its Outcasts (John Wiley \& Sons, 2013).

78 Oliver Bakewell, 'Research Beyond the Categories: The Importance of Policy Irrelevant Research into Forced Migration', Journal of Refugee Studies 21, no. 4 (2008): 449, doi.org/10.1093/jrs/fen042.

79 Jodi Halpern and Harvey M Weinstein, 'Rehumanizing the Other: Empathy and Reconciliation',

Human Rights Quarterly 26, no. 3 (2004): 567, doi.org/10.1353/hrq.2004.0036.

80 Halpern and Weinstein, 'Rehumanizing the Other', 580.

81 Adichie, 'The Danger of a Single Story'. 
another person as a complex, nonidealized individual' ${ }^{82}$ Rehumanising those with refugee experience, beyond the negative, singular stories that are so often represented, requires an acknowledgement that:

there is no intrinsic paradigmatic refugee figure to be at once recognised and registered regardless of historical contingencies. Instead ... there are a thousand multifarious refugee experiences and a thousand refugee figures whose meanings and identities are negotiated in the process of displacement in time and place. ${ }^{83}$

Listening to the voices and representing them in all their complexity can and will help to rehumanise those with refugee experience. Rehumanising understandings of the refugee would enable a shift such that being a refugee is not seen as a negative experience. It is simply one part of the experience that makes up the lives of complex humans. While it is essential that there is increased recognition that those who are resettled in Australia are no longer officially refugees, people with experience as refugees should feel able to identify with this experience in the knowledge that it will not be seen others as a deficit.

82 Halpern and Weinstein, 'Rehumanizing the Other', 574.

83 Nevzat Soguk, States and Strangers: Refugees and Displacements of Statecraft (Minneapolis: University of Minnesota Press, 1999), 4. 
This text is taken from Refugee Journeys: Histories of Resettlement, Representation and Resistance, edited by Jordana Silverstein and Rachel Stevens, published 2021 by ANU Press, The Australian National University, Canberra, Australia.

doi.org/10.22459/RJ.2021.02 